\title{
The Effect of Supercritical Fluid Extraction Parameters on the Swietenia Mahagoni Seed Oil Extraction and its Cytotoxic Properties
}

\author{
Hartatia,c, Liza Md Salleha ${ }^{a}$, Azila Abd. Aziza, Mohd. Azizi Che Yunus ${ }^{b}$ \\ a Department of Bioprocess Engineering, Faculty of Chemical Engineering, Universiti Teknologi Malaysia, 81310 UTM Johor Bahru, Johor, Malaysia \\ ${ }^{b}$ Centre of Lipid Engineering and Applied Research (CLEAR), c/o Faculty of Chemical Engineering, Universiti Teknologi Malaysia, 81310 UTM Johor \\ Bahru, Johor, Malaysia \\ 'Department of Biology, University State of Makassar, South Sulawesi, Indonesia \\ *Corresponding author: i.liza@cheme.utm.my
}

\section{Article history}

Received :5 March 2014

Received in revised form : 19 April 2014

Accepted :3 May 2014

\section{Graphical abstract}

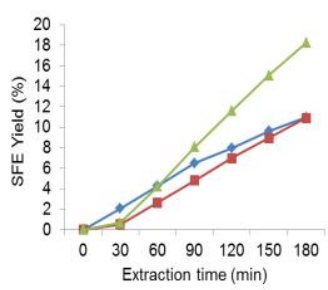

\begin{abstract}
In this study, the influence of supercritical extraction parameter on the oil extraction of Mahogany (Swietenia mahagoni) was investigated. Supercritical extraction was carried out using the operation pressures of 20,25 and $30 \mathrm{MPa}$, and temperature was varied in 40,50 and $60^{\circ} \mathrm{C}$. The parameter used for $\mathrm{CO}_{2}$ flow rate was constant, $2 \mathrm{~mL} / \mathrm{min}$, with extraction time of 180 min by using matrix particle size of $0.75 \mathrm{~mm}$. Then, the extracted oils were tested for cytotoxic activity and properties. MTT assay was used as in vitro study to investigate the cytotoxic properties of the extracted on human fibroblast cells (HSF 1184). The study reveals that the extraction yield depends on the pressure and temperature. There is a significant difference of 40,50 and $60^{\circ} \mathrm{C}$ at different pressures, whereby increasing pressure leads to significant increase extraction yields. MTT assay results indicate that all the extracts under different extraction parameters are non-cytotoxic. The results confirmed that supercritical extraction could be a promising technique to produce high quality botanicals extracts, free of solvent and non-cytotoxic with significant cost savings.
\end{abstract}

Keywords: Swietenia mahagoni; supercritical fluid extraction; cytotoxicity

\begin{abstract}
Abstrak
Dalam kajian ini, pengaruh daripada parameter pengekstrakan lampau genting terhadap pengekstrakan minyak Mahogany (Swietenia mahagoni) telah dikaji. Pengekstrakan lampau genting dilakukan dengan menggunakan pengendalian tekanan 20,25 and $30 \mathrm{MPa}$, dan suhu diubahsuai dengan 40,50 and $60^{\circ} \mathrm{C}$. Seterusnya, aktiviti dan sifat sitotoksik minyak yang diekstrak ini diuji. MTT asai digunakan dalam kajian in vitro untuk menyelidik sifat sitotoksik sel fibroblast manusia (HSF 1184). Kajian ini menyampaikan bahawa hasil daripada pengekstrakan adalah bergantung kepada tekanan dan suhu. Ia menunjukkan perbezaan yang amat ketara pada 40,50 and $60^{\circ} \mathrm{C}$ dengan tekanan yang berbeza, di mana pertambahan tekanan menyebabkan pertambahan hasil pengekstrakan secara mendadak. Keputusan asai MTT menampilkan semua hasil ekstrak di bawah parameter pengekstrakan adalah tidak sitotoksok. Keputusan mengesahkan bahawa pengekstrakan lampau genting boleh dijadikan teknik berpotensi untuk menghasilkan ekstrak botani yang berkualiti tinggi, bebas daripada pelarut, tidak bertoksik, dengan penjimatan kos yang tinggi.
\end{abstract}

Keywords: Swietenia mahagoni; pengekstrakan bendalir lampau genting; toksik

CC 2014 Penerbit UTM Press. All rights reserved.

\subsection{INTRODUCTION}

Swietenia mahagoni seeds have been applied as folk medicine for the treatment of hypertension, malaria, and diabetes [1]. The therapeutic effects associated with the seeds are mainly caused by the biologically active ingredients; fatty acids and tetranortriterpenoids [2]. There have also been reports of $S$. mahagoni seeds having anti-inflammatory, antimutagenecity, and antitumour activities [3].
Supercritical carbon dioxide extraction $\left(\mathrm{SC}-\mathrm{CO}_{2}\right)$ is an attractive alternative to conventional liquid extraction due to its mild environment in the process and no residue of harmful solvents. Furthermore, employing carbon dioxide as a supercritical solvent is a promising technology. It does not affect thermally sensitive materials with its low critical temperature $\left(31.1^{\circ} \mathrm{C}\right)$ and pressure $(7.28 \mathrm{MPa})$, that makes it an ideal solvent for extracting. Furthermore, being non toxic, inflammable, widely available and cheap [4]. Supercritical carbon dioxide $\left(\mathrm{SC}-\mathrm{CO}_{2}\right)$ was 
successfully used in the extraction of edible oils from a wide range of seeds, including amaranth [5], hiprose [6], cuphea [7], flax [8], sunflower and rape [9]. Therefore, the aim of this study is to investigate the supercritical fluid extraction parameters that affect the yield of Swietenia mahagoni seed oil as well as investigating the cytotoxicity of the Swietenia mahagoni extract on human skin fibroblast cells.

\subsection{EXPERIMENTAL}

\subsection{Plant Material Preparation}

Swietenia mahagoni seeds were collected from Indonesia. The seeds were rinsed with tap water to remove any foreign particles and dirt prior to drying. Then, the cleaned seeds were cut into small pieces and dried in an oven at the temperature of $50{ }^{\circ} \mathrm{C}$ for one week to remove the moisture. The seeds were then ground in a blender.

\subsection{Supercritical $\mathrm{CO}_{2}$ Extraction}

The schematic diagram of SFE apparatus for the extraction of Swietenia mahagoni seed is illustrated in Figure 1. $5 \mathrm{~g}$ of ground sample was placed in an extractor vessel. Two independent variables studies were extraction pressure $(\mathrm{MPa})$ and temperature $\left({ }^{\circ} \mathrm{C}\right)$. These independent variables and their levels were selected based on the preliminary experiments in our laboratory (data not shown). The oil was extracted at temperature of 40,50 and $60{ }^{\circ} \mathrm{C}$ with operating pressure of 20,25 , and $30 \mathrm{MPa}$ using carbon dioxide flow rate of $2 \mathrm{~mL} / \mathrm{min}$ and extraction time of $180 \mathrm{~min}$. After each extraction, the obtained extract was placed into glass vials. The oil yield was calculated by the weight increment at the end of the extraction and keep at $-20^{\circ} \mathrm{C}$ for analysis.

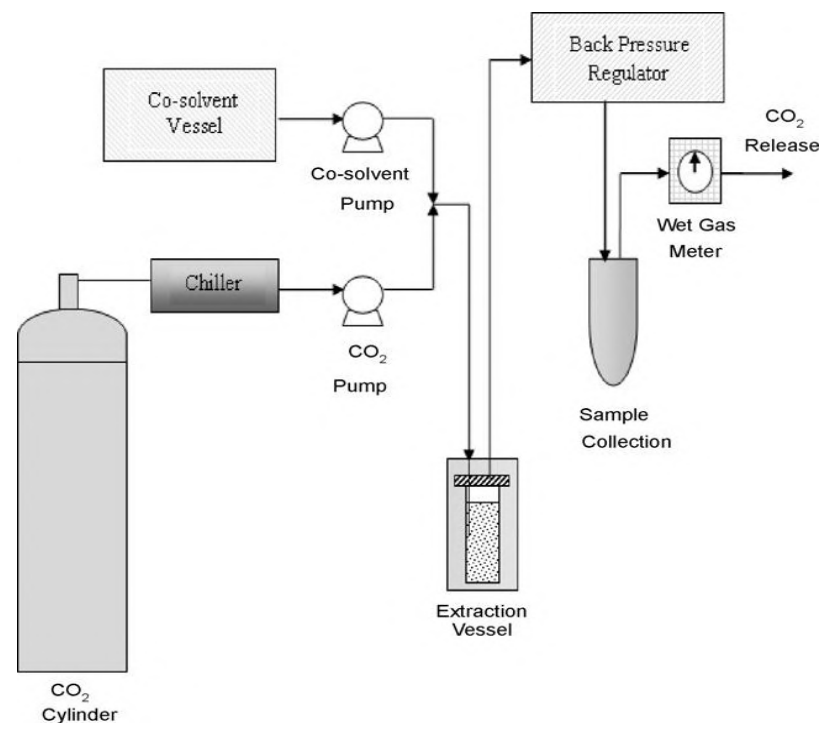

Figure 1 Schematic design of the supercritical fluid extraction (SFE) unit

\subsection{Cytotoxicity Test}

The cytotoxicity testing of Swietenia mahagoni was examined by using 3-[4,5-dimethyl-thiazol-2-yl]-2,5-diphenyl tetrazolium bromide (MTT) assay as described in literature [10]. The human skin fibroblast (HSF 1184) cells proliferation activity of crude extracts was evaluated by using MTT colorimetric assay. All cells were cultured in minimum essential medium (MEM) supplemented with $10 \%$ fetal bovine serum (FBS) and $1 \%$ pen Strype (PS) under 5\% $\mathrm{CO}_{2}$ humidified incubator. The cells were seeded at a density of $2 \times 10^{5}$ cells/well in 96-well plate excluded the first row and incubated for 24 hours prior to treatment. The test samples were prepared by dissolving extract in MEM to yield the final concentration of the crude extracts of S.mahagoni $(10,1$, $0.1,0.01,0.001,0.0001 \mathrm{mg} / \mathrm{mL}$, respectively). The medium was replaced after 24 hours with $200 \mu \mathrm{L}$ of MEM containing $10 \%$ FBS and 1\% PS and serial dilution of plant extracts. After incubation, the cells were washed with phosphate buffered saline (PBS), $20 \mu \mathrm{L}$ of freshly prepared MTT solution $(5 \mathrm{mg} / \mathrm{mL})$ was added into each well and cells were incubated at $37^{\circ} \mathrm{C}$ for 5 hours. The MTT solution was then removed and replaced with $200 \mu \mathrm{L}$ of DMSO to allow dissolution of the purple MTT formazon crystal. The absorbance was measured at $540 \mathrm{~nm}$ using ELISA plate reader.

\subsection{RESULTS AND DISCUSSION}

\subsection{Effect of the Process Parameters on the Yield}

In this study, the effects of temperature and pressure on the extraction yield of Swietenia mahagoni seed oil were investigated. The selection of operation parameters was based on the preliminary experiments done in our laboratory. The matrix particle size of the samples was fixed at $0.75 \mathrm{~mm}$, as the reduction of particle size can result in the increase of the extraction yield and the extracted compound. This has been revealed by many researchers $[9,11]$.

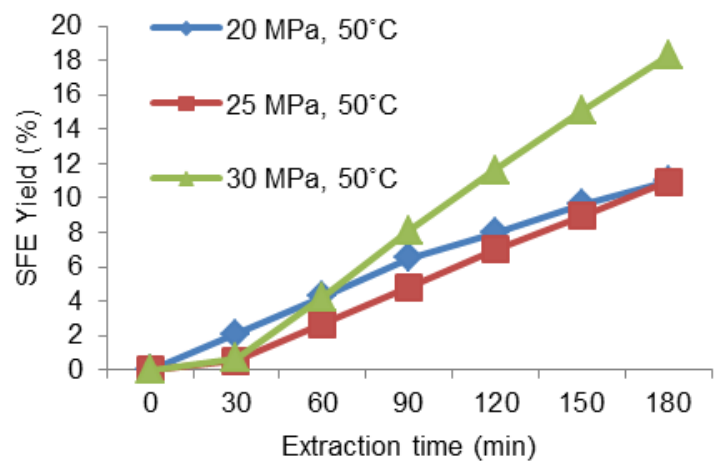

Figure 2 The effect of extraction pressure on the supercritical fluid extraction yield

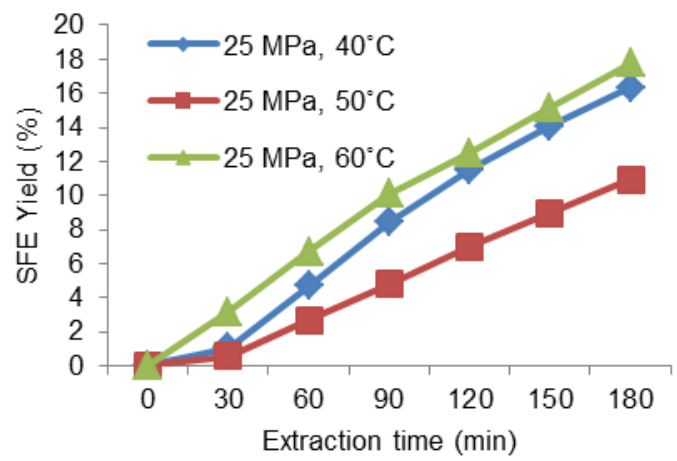

Figure 3 The effect of extraction temperature on the supercritical fluid extraction yield 
The extraction yield increased with increasing pressure at constant operating temperature as shown in Figure 2 . At $50^{\circ} \mathrm{C}$, more yields were obtained using different range of pressure and the highest oil yield was recorded at $18.25 \%$, at the pressure of $30 \mathrm{MPa}$. While at $20 \mathrm{MPa}(10.97 \%)$ and $25 \mathrm{MPa}(10.91 \%)$, the oil yield was less compared to the extracted yield at $30 \mathrm{MPa}$. Therefore, extraction oil yield of Swietenia mahagoni seed increased with increasing pressure at constant temperature. This was due to the increase in $\mathrm{CO}_{2}$ 's density and consequently dissolving ability. In this study, the operating temperature was selected at 40,50 , and $60^{\circ} \mathrm{C}$. The results show that with an increase in temperature from $40{ }^{\circ} \mathrm{C}$ to 50 ${ }^{\circ} \mathrm{C}$ at $24 \mathrm{MPa}$, the Swietenia mahagoni seed oil dropped from $16.35 \%$ to $10.91 \%$ and oil yield increased from $10.91 \%$ to $17.74 \%$ when temperature was increased from $50{ }^{\circ} \mathrm{C}$ to $60{ }^{\circ} \mathrm{C}$ at $25 \mathrm{MPa}$, as shown in Figure 3. A similar trend was reported for the extraction of Sylibium marianum oil using $\mathrm{SC}-\mathrm{CO}_{2}$. In this case, the seed oil yield decreased from $19.9 \%$ to $5.2 \%$ when the temperature increased from $25^{\circ} \mathrm{C}$ to $80{ }^{\circ} \mathrm{C}$ at $20 \mathrm{MPa}$, but at 30 $\mathrm{MPa}$ the temperature increased from $15.3 \%$ to $20.5 \%$ [12]. In fact, the pressure increase seems to have more substantial effect on the oil yield than the temperature increase.

\subsection{Cytotoxicity Test}

Cell proliferation (cytotoxicity) assay were performed to test the possible cytotoxicity of Swietenia mahagoni seed using supercritical fluid extraction. The proliferation of human skin fibroblast was evaluated by MTT assay with different concentrations of various parameters condition of extracts (Figure 4 and 5). The data showed that Swietenia mahagoni seed has an extremely low toxicity on human skin fibroblast at 10 until 1 $\mathrm{mg} / \mathrm{mL}$ (Figure 4). The low cytotoxic effects on fibroblast suggest that Swietenia mahagoni can be classified as a non-toxic substance and can be used safely for external application and wound dressing. Generally, this result indicates that all the extracts of Swietenia mahagoni exhibited no cytotoxic effect on fibroblast cell, noncytotoxic and safe for medical use. However, this result are supported by adjusting the extraction condition in supercritical fluid extraction, a safe and clean extract which is solvent-free with high purity and noncytotoxic can be obtained.

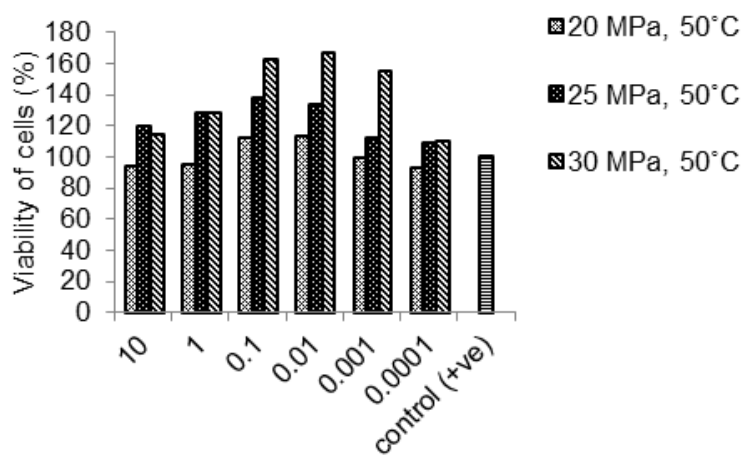

Concentration of Swietenia mahagoni $(\mathrm{mg} / \mathrm{ml})$

Figure 4 Effect of Swietenia mahagoni seed extracts at parameters condition (pressure of $20,25,30 \mathrm{MPa}$, temperature of $50{ }^{\circ} \mathrm{C}$ ) on human skin fibroblast (HSF 1184) cell using MTT assay

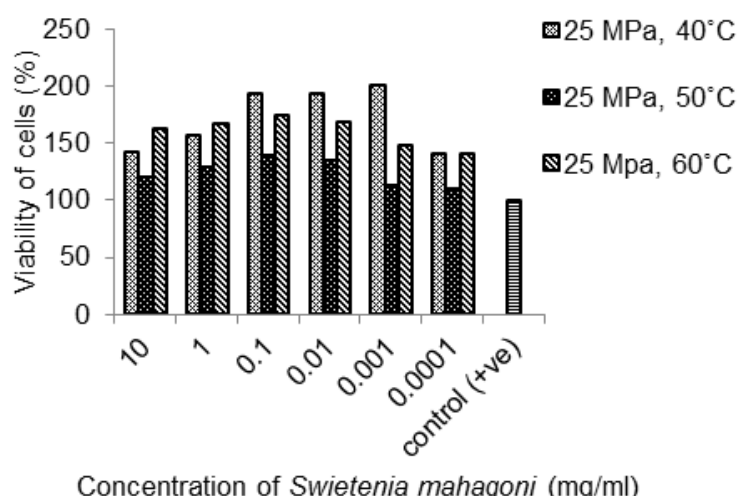

Figure 5 Effect of Swietenia mahagoni seed extracts at parameters condition (pressure $25 \mathrm{MPa}$, temperature of 40,50 and $60{ }^{\circ} \mathrm{C}$ ) on human skin fibroblast (HSF 1184) cell using MTT assay.

\subsection{CONCLUSION}

The extraction yield of Swietenia mahagoni oil increased with increasing pressure and temperature. The results of this experiment indicate that all extracts of Swietenia mahagoni seed oil is non-cytotoxic and safe for medical use, which shows that Swietenia mahagoni seed oil has potential to be used in the treatment of wound healing. Moreover, these results confirmed that supercritical fluid extraction technology can be applied in pharmacology and drug discovery to produce high quality extracts for treatment of diseases.

\section{Acknowledgement}

The authors are highly grateful to the financial support from Universiti Teknologi Malaysia under GUP (Q.J130000.7125.02H01).

\section{References}

[1] Y. Y. Chen, X. N. Wang, C. Q. Fan, S. Yin, J. M. Yue. 2007. Tetrahedron Lett. 48: 7480-7484.

[2] K. Bacsal, L. Chavez, I. Diaz, S. Espina, J. Javillo, H. Manzanilla, J. Motalban, C. Panganiban, A. Rodriguez, C. Sumpaico, B. Talip, S. Yap. 1997. Acta Med. Philipp. 3: 127-139.

[3] A. P. Guevara, A. Apilado, H. Sakurai, M. Kozuka, H. Tokuda. 1996. J. Sci. 125: 271-278.

[4] N. A. Nik Norulani, I. S. Zaidul, O. Anuar, A. K. Omar. 2004. Purif Technol. 35: 55-60.

[5] D. Westerman, R. C. D. Santos, J. A. Bosley, J. S. Roger, B. Al-Duri. 2006. J. Supercrit Fluids. 37: 38-52.

[6] E. Reverchon, A. Kaziunas, C. Marrone. 2000. Chem. Eng. Sci. 55: 2195 2201.

[7] F. J. Eller, S. C. Cermak, S. I. Taylor. 2011. Ind. Crop. Prod. 33: 554-557.

[8] S. G. Ozkal. 2009. J. Am. Oil Chem. Soc. 86: 1129-1135.

[9] O. Boutin, E. Badens. 2009. J. Food Eng. 92: 396-402.

[10] E. Ranzato, S. Martinotti, B. Burlando, 2011. J. Ethnopharmacol. 134: 443-449.

[11] C. B. Spricigo, L. T. Pinto, A. Bolzan, A. F. Novais. 1999. Extraction of Essential Oil and Lipids from nutmeg by Liquid Carbon Dioxide. $J$. Supercrit. Fluids. 15: 253-259.

[12] J. L. Martinez. 2008. Supercritical Fluid Extraction of Nutraceuticals and Bioactive Compounds. CRC Press Taylor \& Francis Group LLC. 